\title{
ANALISIS KEMAMPUAN BERPIKIR KRITIS MATEMATIS SISWA SMP PADA MATERI PYTHAGORAS
}

\author{
Angga Andriawan ${ }^{1}$, Asti Sari Setiawati ${ }^{2}$, Indah Puspita Sari ${ }^{3}$, Siti Chotimah $^{4}$ \\ 1,2,3,4 IKIP Siliwangi \\ 1anggaandriawan26101995@gmail.com, ${ }^{2}$ astisaris30@gmail.com, \\ 3indah@ikipsiliwangi.ac.id, ${ }^{4}$ chotimah019@gmail.com
}

\begin{abstract}
This study aims to analyze the critical thinking skills of junior high school students on Pythagoras material. Subjects in this study are students of class VIII-F in SMP Negeri 1 Ngamprah with the number of students 37 people. The method used in this research is qualitative descriptive. This type is chosen because it aims to describe the skills of students in solving problems of mathematical critical thinking independently. The research phase is divided into three, namely planning, implementation, and reporting. The technique of collecting data in the form of test. Data analysis techniques based on indicators of mathematical critical thinking skills that has been determined by researchers include: (1) identifying the concepts used in problem solving, (2) formulating an action (strategy, tactics, or approach) in solving problems, (3) providing arguments or reasons for answering and solving problems, and (4) evaluating evidence or decisions taken in solving the problem. The results obtained quantitatively show that the level of mathematical critical thinking skills of students in SMP Negeri 1 Ngamprah in solving the problems on Pythagoras material still falls into the low category. The evidence from the percentage of each indicator with the highest rate of only $61 \%$. Some factors influence the level of students critical thinking skills, including the preparation of incomplete and appropriate strategies, provide arguments without showing the truth, and the students' accuracy in working on the questions.
\end{abstract}

Keywords: Mathematical Critical Thinking, Pythagoras

\begin{abstract}
Abstrak
Penelitian ini bertujuan untuk menganalisis kemampuan berpikir kritis matematis siswa SMP pada materi pythagoras. Subjek dalam penelitian ini adalah siswa kelas VIII-F di SMP Negeri 1 Ngamprah dengan jumlah siswa 37 orang. Metode yang digunakan dalam penelitian ini adalah kualitatif deskriptif. Jenis ini dipilih karena bertujuan untuk menggambarkan kemampuan siswa dalam menyelesaikan soal-soal berpikir kritis matematis secara mandiri.Tahap penelitian terbagi menjadi tiga, yaitu perencanaan, pelaksanaan, dan pelaporan. Teknik pengumpulan data berupa tes. Teknik analisis data berdasarkan indikator kemampuan berpikir kritis matematis yang telah ditetapkan peneliti yang meliputi: (1) menentukan konsep yang digunakan dalam penyelesaian masalah, (2) merumuskan suatu tindakan (strategi, taktik, atau pendekatan) dalam menyelesaikan masalah, (3) memberikan argumen atau alasan dalam menjawab dan menyelesaikan masalah, dan (4) mengevaluasi bukti atau keputusan yang telah diambil dalam menyelesaikan masalah. Hasil yang diperoleh secara kuantitatif menunjukkan bahwa tingkat kemampuan berpikir kritis matematis siswa di SMP Negeri 1 Ngamprah dalam menyelesaikan soal-soal pada materi pythagoras masih termasuk ke dalam kategori rendah. Hal tersebut terlihat dari persentase pada setiap indikator dengan persentase tertinggi hanya mencapai 61\%.Terdapat faktor yang mempengaruhi tingkat kemampuan berpikir kritis siswa, diantaranya penyusunan strategi yang tidak lengkap dan tepat, memberikan argumen tanpa menunjukkan bukti kebenarannya, dan ketelitian siswa dalam mengerjakan soal.
\end{abstract}

Kata Kunci: Berpikir Kritis Matematis, Pythagoras 
How to cite: Andriawan, A., Setiawati, A. S., Sari, I. P., Chotimah, S. (2018). Analisis Kemampuan Berpikir Kritis Matematis Siswa SMP pada Materi Pythagoras. JPMI - Jurnal Pembelajaran Matematika Inovatif, 1 (4), 559-568.

\section{PENDAHULUAN}

Pendidikan merupakan hal yang perlu ditempuh oleh seluruh manusia. Pendidikan menjadi faktor penentu maju tidaknya seseorang. Oleh karena itu, pendidikan yang diselenggarakan harus mengarahkan anak didik untuk dapat aktif, kritis, dan kreatif. Hal tersebut perlu didukung dengan adanya perkembangan pada proses pembelajaran di kelas, terutama dalam pembelajaran matematika. (Chotimah, et al., 2018) mengatakan "Mathematics is an important part that cannot be separated from human life" maksudnya Matematika adalah bagian yang sangat penting yang tidak dapat dipisahkan dari kehidupan manusia, sehingga matematika perlu diperkenalkan sejak dini.

Sujono (Rosyana \& Sari, 2015) menyatakan bahwa matematika perlu diajarkan di sekolah karena matematika menyiapkan siswa menjadi pemikir dan penemu, matematika menyiapkan siswa menjadi warga negara yang hemat, cermat, dan efisien dan matematika membantu siswa membangun karakternya. Matematika merupakan bidang pendidikan yang berpotensi untuk meningkatkan kemampuan berpikir dan beragumentasi, ikut serta dalam penyelesaian masalah sehari-hari. Dalam proses pembelajaran matematika perlu adanya peningkatan dan penekanan pada kemampuan berpikir tingkat tinggi dari peserta didik. Salah satu dari kemampuan berpikir tingkat tinggi tersebut adalah kemampuan berpikir kritis matematis.

Menurut Ennis (Sari, et al., 2016), kemampuan berpikir kritis merupakan kemampuan berpikir logis dan reflektif yang difokuskan pada pengambilan keputusan yang dipercayai atau dilakukan. Sementara itu, Yaumi (Widiantari et al., 2016) menyatakan berpikir kritis merupakan kemampuan kognitif dalam pengambilan kesimpulan berdasarkan alasan logis dan bukti empiris. Pengertian berpikir kritis tersebut dilengkapi lagi oleh Eggen dan Don (Widiantari et al., 2016) bahwa pada kesimpulan yang dibuat juga cenderung dilakukan assesment (penilaian) berdasarkan bukti.

Kemampuan berpikir kritis terbagi menjadi 6 yaitu: (1) basic clarification, (2) the bases for adecision, (3) inference, (4) advanced clarification, (5) supposition and integration, dan (6) auxiliary abilities (non constitutive of critical thinking, but very helpful (Hidayat, 2011; 2012; Sari et al., 2016; Sumarmo, Hidayat, Zukarnaen, Hamidah, \& Sariningsih, 2012; Tresnawati, Hidayat, \& Rohaeti, 2017). Sedangkan Fisher (Fristadi dan Bharata, 2015) mengemukakan enam indikator berpikir kritis yaitu: (1) Mengidentifikasi masalah, (2) Mengumpulkan berbagai informasi yang relevan, (3) Menyusun sejumlah alternatif pemecahan masalah, (4) Membuat kesimpulan, (5) Mengungkapkan pendapat, dan (6) Mengevaluasi argumen. Berdasarkan uraian di atas, indikator kemampuan berpikir kritis matematis yang akan digunakan dalam penelitian ini yaitu: (1) menentukan konsep yang digunakan dalam penyelesaian masalah, (2) merumuskan suatu tindakan (strategi, taktik, atau pendekatan) dalam menyelesaikan masalah, (3) memberikan argumen atau alasan dalam menjawab dan menyelesaikan masalah, dan (4) mengevaluasi bukti atau keputusan yang telah diambil dalam menyelesaikan masalah.

Penelitian ini bertujuan untuk mengetahui kemampuan berpikir kritis siswa kelas VIII SMP Negeri 1 Ngamprah pada materi Pythagoras. Dengan adanya penelitian ini, diharapkan dapat 
memberikan gambaran kepada guru matematika tentang kondisi kemampuan berpikir kritis siswa, sehingga guru dapat merancang kegiatan pembelajaran yang dapat mengajak siswa untuk melatih kemampuan berpikir kritisnya.

\section{METODE}

Metode yang digunakan pada penelitian ini adalah kualitatif deskriptif. Jenis ini dipilih karena bertujuan untuk menggambarkan kemampuan siswa dalam menyelesaikan soal-soal berpikir kritis matematis secara mandiri.Subjek dalam penelitian ini adalah kelas VIII-F di SMP Negeri 1 Ngamprah, Semester Genap Tahun Akademik 2017-2018. Instrumen dalam penelitian ini adalah tes uraian yang terdiri dari 5 soal kemampuan berpikir kritis matematis pada materi pythagoras. Dalam penelitian ini terbagi menjadi tiga tahap, yaitu perencanaan, pelaksanaan, dan pelaporan. Pada tahap perencanaan, peneliti menyiapkan perangkat instrumen kemampuan berpikir kritis matematis meliputi kisi-kisi soal, lembar kerja jawaban, dan penskoran. Selanjutnya pada tahap pelaksanaan, siswa diberi tes kemampuan berpikir kritis matematis. Pada tahap laporan, peneliti mengolah data yang diperoleh selama penelitian berlangsung dan menyusun laporan. Hasil kemampuan berpikir kritis tersebut diukur berdasarkan kategori yang diadaptasi oleh Setyowati (Karim \& Normaya, 2015). Di bawah ini disajikan kategori persentase kemampuan berpikir kritis matematis pada Tabel 1.

Tabel 1. Kategori Persentase Kemampuan Berpikir Kritis Matematis

\begin{tabular}{cc}
\hline Interpretasi $(\%)$ & Kategori \\
\hline $81,25<\mathrm{X} \leq 100$ & Sangat tinggi \\
$71,5<\mathrm{X} \leq 81,25$ & Tinggi \\
$62,5<\mathrm{X} \leq 71,5$ & Sedang \\
$43,75<\mathrm{X} \leq 62,5$ & Rendah \\
$0<\mathrm{X} \leq 43,75$ & Sangat rendah \\
\hline
\end{tabular}

\section{HASIL DAN PEMBAHASAN}

\section{Hasil}

Penelitian yang dilaksanakan pada siswa kelas VIII di SMP Negeri 1 Ngamprah tahun ajaran 2017-2018 dengan jumlah siswa 37 orang. Peneliti memberikan 5 butir soal kemampuan berpikir kritis matematis dengan materi Pythagoras. Dibawah ini akan dideskripsikan hasil tes kemampuan berpikir kritis matematis yang disajikan pada Tabel 2.

Tabel 2. Hasil Tes Kemampuan Berpikir Kritis Matematis

\begin{tabular}{clccc}
\hline No. & \multicolumn{1}{c}{ Indikator } & $\%$ & Kategori \\
\hline 1. & $\begin{array}{l}\text { Menentukan konsep yang digunakan dalam } \\
\text { penyelesaian masalah }\end{array}$ & 60 & Rendah \\
2. $\begin{array}{l}\text { Merumuskan suatu tindakan (strategi, taktik, atau } \\
\text { pendekatan) dalam menyelesaikan masalah }\end{array}$ & 61 & Rendah \\
3. $\begin{array}{l}\text { Memberikan argumen atau alasan dalam menjawab } \\
\text { dan menyelesaikan masalah }\end{array}$ & 24 & $\begin{array}{c}\text { Sangat } \\
\text { Rendah } \\
\text { Sangat }\end{array}$ \\
4. $\begin{array}{l}\text { Mengevaluasi bukti atau keputusan yang telah } \\
\text { diambil dalam menyelesaikan masalah }\end{array}$ & 24 & Rendah \\
\hline
\end{tabular}


Berdasarkan hasil penelitian yang telah dilakukan, dapat diketahui bahwa kemampuan berpikir kritis matematis dari subjek penelitian memiliki ketercapaian pada indikator 1 dan 2 dengan kategori rendah serta pada indikator 3 dan 4 dengan kategori sangat rendah. Berikut disajikan beberapa jawaban siswa yang menjawab tepat dan kurang tepat pada setiap indikator.

1. Jawaban siswa pada indikator pertama yaitu menentukan konsep yang digunakan dalam penyelesaian masalah yang terdapat pada soal nomor 1 dan $2 \mathrm{a}$.

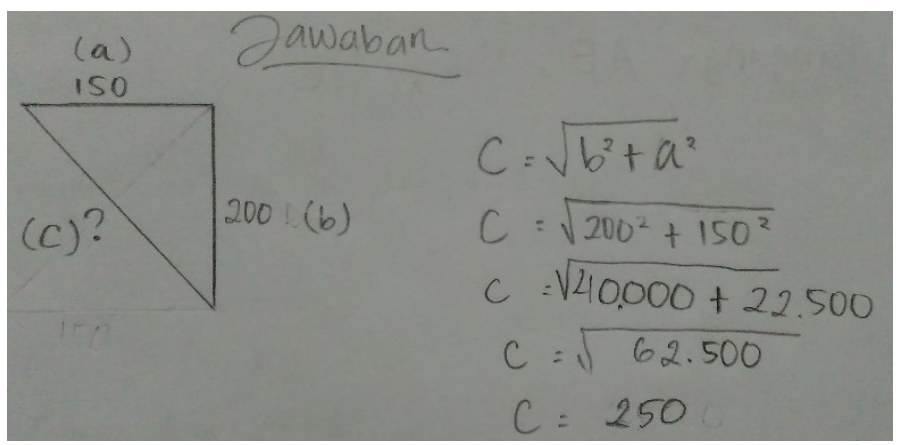

(Gambar 1)

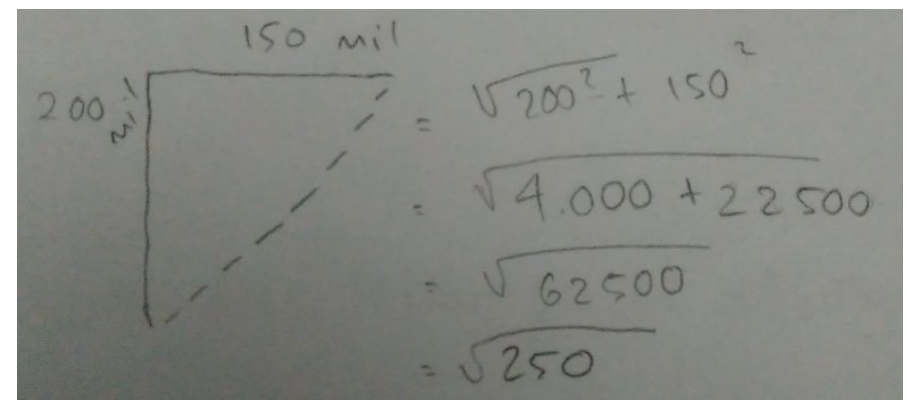

(Gambar 2)

Berdasarkan Gambar 1, siswa A sudah mampu menentukan konsep yang akan digunakan untuk menyelesaikan masalah yang disajikan pada nomor 1 dan dapat menyelesaikan soal tersebut dengan benar. Sedangkan berdasarkan Gambar 2, siswa B keliru dalam membuat sketsa dari soal tersebut. Terlihat bahwa setelah berlayar ke Utara, kapal tersebut malah memutar haluan ke arah Timur yang mana seharusnya kapal tersebut memutar haluan ke arah Barat. Dalam menentukan konsep yang digunakan untuk menyelesaikan masalah yang terdapat pada nomor 1 sudah benar, tetapi dalam perhitungannya masih kurang tepat. Seharusnya ketika akar 62.500 sudah diakarkan, maka hasilnya adalah 250 tanpa menggunakan akar kembali.

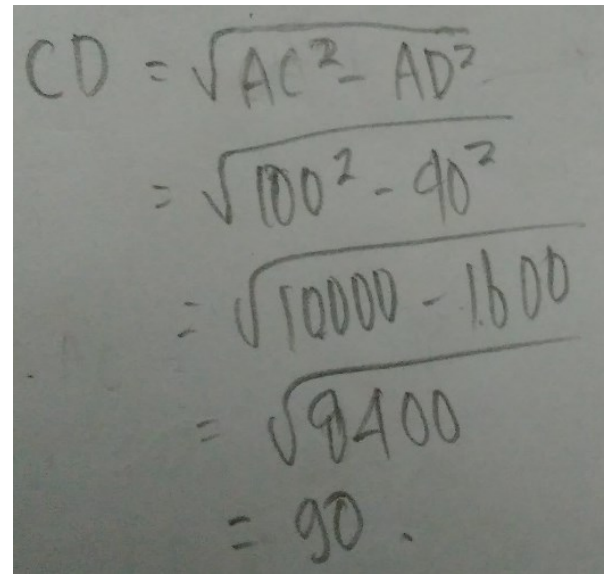


(Gambar 3)

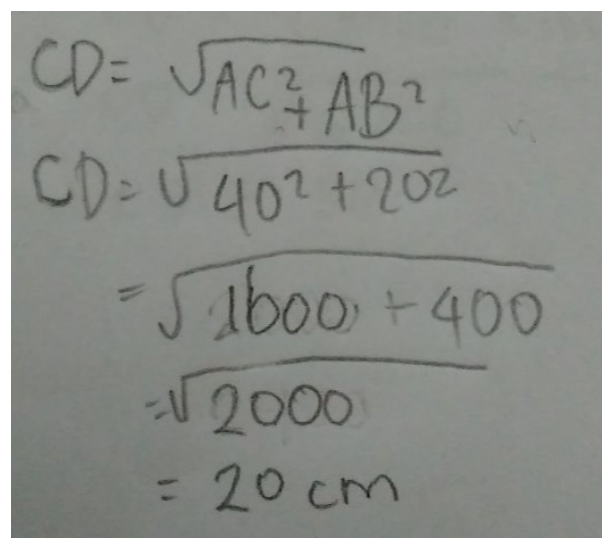

(Gambar 4)

Berdasarkan Gambar 3, siswa C sudah dapat menentukan konsep apa yang akan digunakan untuk menyelesaikan masalah yang terdapat pada nomor 2a, tetapi masih salah dalam mensubstitusikan panjang AC. Terlihat bahwa siswa tersebut mengira bahwa panjang AC adalah $100 \mathrm{~m}$. Hal ini mengakibatkan jawaban siswa tersebut kurang tepat. Sedangkan berdasarkan Gambar 4, siswa D keliru dalam menentukan konsep apa yang akan digunakan untuk menyelesaikan masalah yang terdapat pada nomor 2a. Terlihat bahwa untuk mencari panjang $\mathrm{CD}$, rumus pythagoras yang digunakan adalah keliru. Yang mana seharusnya untuk mencari panjang $\mathrm{CD}$ menggunakan rumus $\sqrt{\mathrm{AC}^{2}-\mathrm{AD}^{2}}$ atau bisa dengan menggunakan kesebangunan.

2. Jawaban siswa pada indikator kedua yaitu merumuskan suatu tindakan (strategi, taktik, atau pendekatan) dalam menyelesaikan masalah yang terdapat pada soal nomor $2 \mathrm{~b}$ dan 3 .

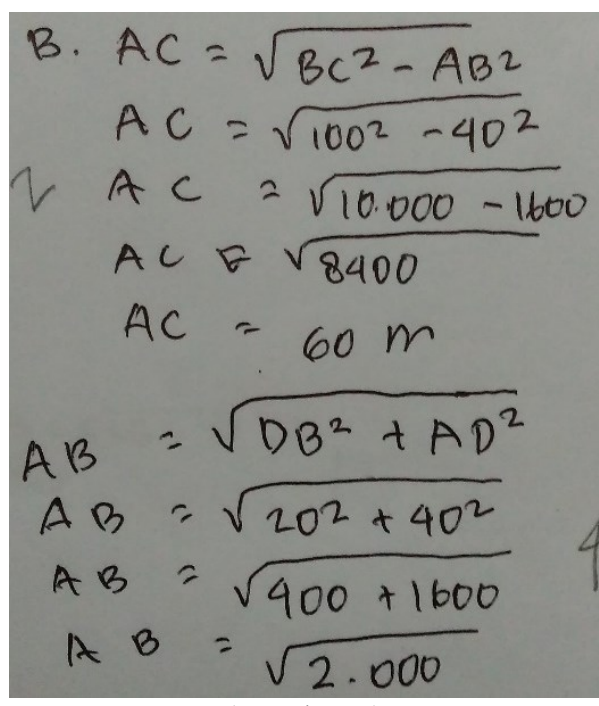

(Gambar 5)

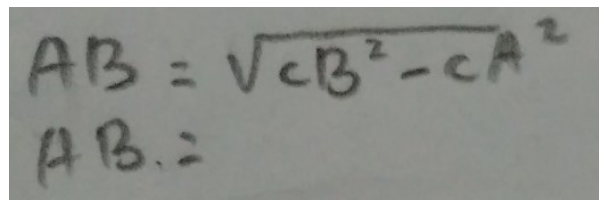

(Gambar 6) 


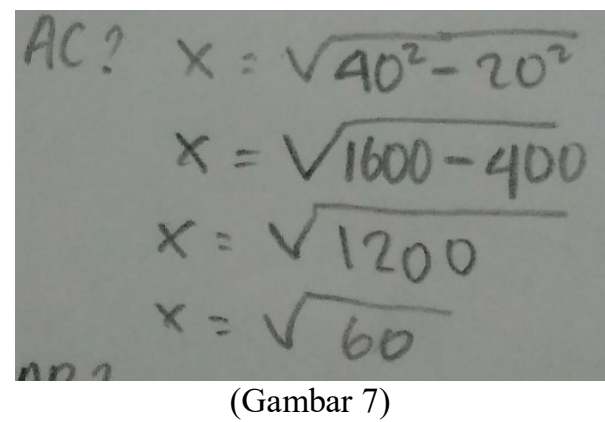

Berdasarkan Gambar 5, siswa E mampu merumuskan strategi untuk menyelesaikan permasalahan pada soal nomor $2 \mathrm{~b}$ akan tetapi belum mampu diselesaikan dengan tepat, dalam mencari panjang $\mathrm{AB}$ sudah benar tetapi dalam mencari panjang $\mathrm{AC}$ masih keliru karena siswa ini masih terkendala dalam penemuan hasil akar suatu bilangan. Berdasarkan Gambar 6, siswa F mampu merumuskan strategi untuk menyelesaikan permasalahan pada soal nomor $2 \mathrm{~b}$ akan tetapi tidak dilanjutkan dalam perhitungannya, kemungkinan siswa tersebut bingung dalam mensubstitusikan panjang $\mathrm{CB}$ dan panjang $\mathrm{CA}$ yang harus dicari dahulu dengan menggunakan kesebangunan. Berdasarkan Gambar 7, siswa G belum mampu merumuskan strategi untuk menyelesaikan permasalahan pada soal nomor $2 \mathrm{~b}$. Terlihat dalam mencari panjang $\mathrm{AC}$, rumus yang digunakan adalah $\sqrt{\mathrm{AD}^{2}-\mathrm{BD}^{2}}$ yang mana seharusnya rumus yang digunakan adalah $\sqrt{\mathrm{AD}^{2}+\mathrm{CD}^{2}}$ atau $\sqrt{\mathrm{AB}^{2}+\mathrm{BC}^{2}}$.

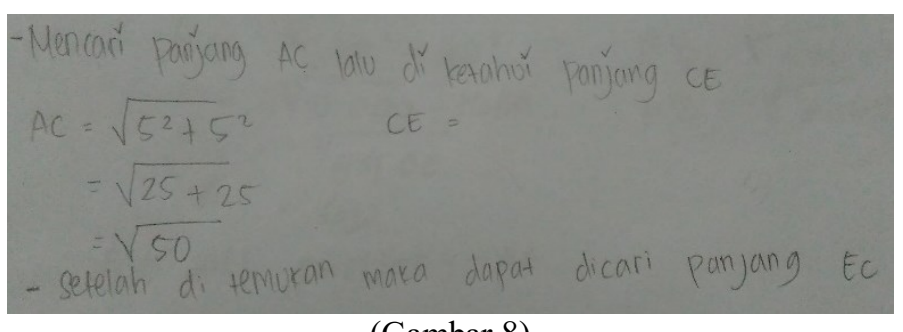

(Gambar 8)

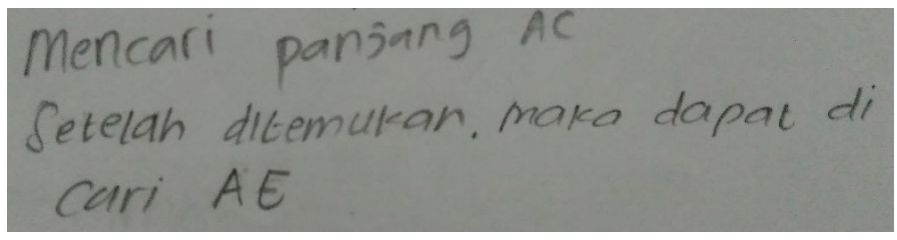

(Gambar 9)

Berdasarkan Gambar 8, siswa $\mathrm{H}$ mampu merumuskan strategi untuk menyelesaikan permasalahan pada soal nomor 3 akan tetapi jawaban siswa tersebut belum selesai. Siswa tersebut hanya mencari panjang AC saja tanpa mencari panjang CE. Berdasarkan Gambar 9, siswa I belum mampu merumuskan strategi untuk menyelesaikan permasalahan pada soal nomor 3. Siswa tersebut langsung menggunakan rumus untuk mencari panjang $\mathrm{CE}$ tanpa menghitung terlebih dahulu panjang AC.

3. Jawaban siswa pada indikator ketiga yaitu memberikan argumen atau alasan dalam menjawab dan menyelesaikan masalah yang terdapat pada soal nomor $4 \mathrm{~b}$ dan 5 .

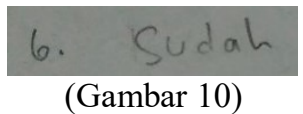

Berdasarkan Gambar 10, jawaban siswa B dalam menyelesaikan permasalahan pada nomor 4bbelum tepatdan belum mampu memberikan argumen atau alasan dalam menyelesaikan masalah yang diberikan. 


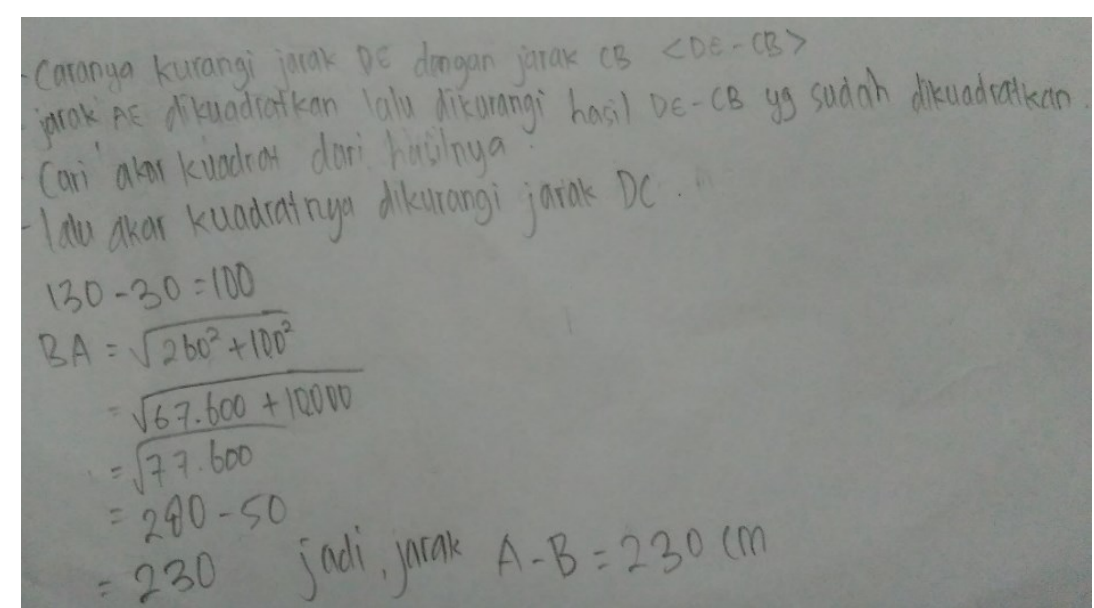

(Gambar 11)

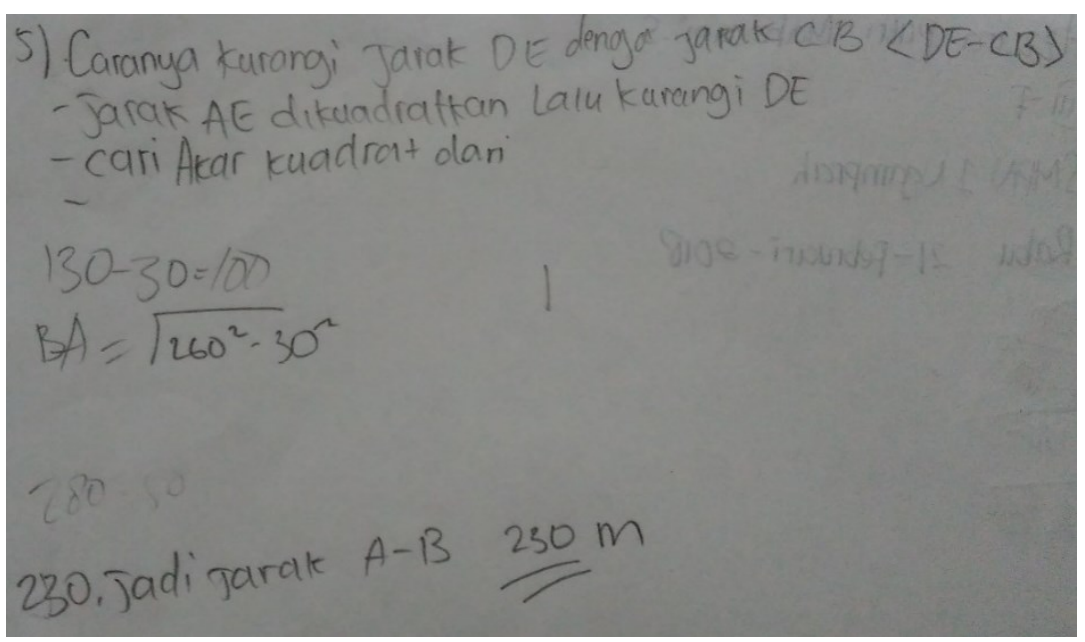

(Gambar 12)

Berdasarkan Gambar 11, siswa C sudah dapat memberikan argumenatau alasan dalam menjawab dan menyelesaikan masalah yang disajikan pada soal nomor 5 dengan tepat, hanya saja strategi yang digunakan untuk menemukan solusi dari permasalahan tersebut masih kurang tepat. Sedangkan berdasarkan Gambar 12, siswa J sudah dapat memberikan argumen atau alasan dalam menjawab dan menyelesaikan masalah yang terdapat pada soal nomor 5 tetapi masih keliru. Serta dalam menentukan strategi yang digunakan untuk menemukan solusi dari permasalahan tersebut masih kurang tepat.

4. Jawaban siswa pada indikator keempat yaitu mengevaluasi bukti atau keputusan yang telah diambil dalam menyelesaikan masalah yang terdapat pada soal nomor $4 a$.

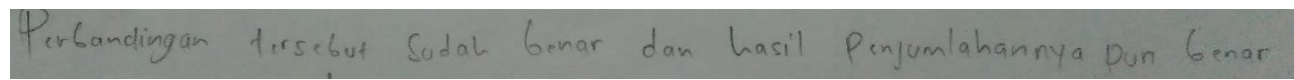

(Gambar 13)

Berdasarkan Gambar 13, siswa C menunjukkan bahwa pada soal nomor 4a siswa tersebut hanya menganalisis soal yang disajikan tanpa menunjukkan bukti kebenarannya sehingga keputusan yang telah diambilnya tersebut adalah keliru.

\section{Pembahasan}

Dari hasil analisis yang dilakukan terhadap indikator-indikator kemampuan berpikir kritis matematis menunjukkan bahwa kemampuan berpikir kritis matematis siswa masih tergolong rendah. Hal ini sesuai dengan hasil penelitian yang menunjukkan bahwa kemampuan berpikir kritis matematis siswa masih tergolong rendah (Sari et al., 2017). Hasil tersebut bisa 
disebabkan karena kurangnya pemahaman konsep dasar atau bisa karena metode yang diterapkan oleh guru dalam penyampaian materi pythagoras kurang memuat siswa untuk dapat berpikir kritis. Selain itu, bisa pula dikarenakan kurangnya latihan dalam menyelesaikan soal-soal berkemampuan tingkat tinggi seperti tes kemampuan berpikir kritis. Kemampuan berpikir kritis siswa akan berkembang apabila didukung dengan upaya-upaya yang dilakukan oleh guru. Hal ini sejalan dengan pendapat Hamalik (Widiantari et al., 2016) yang mengemukakan bahwa penggunaan media pembelajaran yang lebih variatif akan membuat pelajaran lebih menarik, menjadi lebih konkrit, mudah dipahami, dan hasil belajar menjadi lebih bermakna.Sementara itu, National Research Council (Sari et al., 2017) menjelaskan bahwa kemungkinan berkembangnya kemampuan berpikir kritis yaitu pengalamanpengalaman individu yang diperoleh melalui proses menyelesaikan masalah matematika. Akan tetapi, setiap siswa memiliki kemampuan yang berbeda dalam memahami materi yang diajarkan dan menyelesaikan masalah. Sumiati (Widiantari et al., 2016) menyatakan bahwa apa yang dipelajari secara cepat, mungkin tidak dapat dilakukan oleh yang lain dengan cara yang sama. Oleh karena itu, dalam pembelajaran harus memperhatikan tingkat kemampuan siswa.

\section{KESIMPULAN}

Berdasarkan pada hasil dan pembahasan dapat disimpulkan bahwa kemampuan berpikir kritis matematis siswa di SMP Negeri 1 Ngamprah masih termasuk dalam kategori rendah dan perlu adanya upaya untuk meningkatkan serta mengembangkan kemampuan tersebut. Dari hasil tes yang diperoleh pada setiap indikator yang sudah cukup baik yaitu pada indikator yang kedua akan tetapi pada indikator tersebut masih saja perlu ditingkatkan sebab hasil persentasenya pun hanya $61 \%$. Sementara tiga indikator yang lainnya masih sangat perlu ditingkat melihat persentasenya pun hanya mampu mencapai $60 \%$. Hasil penelitian ini memberikan gambaran kepada guru dan para peneliti tentang kondisi kemampuan berpikir kritis matematis siswa SMP kelas VIII. Diharapkan dengan kondisi seperti ini guru dapat memberikan banyak stimulus soal-soal yang memuat kemampuan berpikir tingkat tinggi yang salah satunya adalah kemampuan berpikir kritis matematis agar kemampuan siswa dalam kognitif tersebut terus berkembang dengan baik. Selain itu, guru harus memiliki kemampuan untuk menerapkan metode yang tepat dalam menyajikan suatu materi agar siswa lebih mudah memahaminya.

\section{UCAPAN TERIMA KASIH}

Diucapkan terima kasih kepada Indah Puspita Sari, S.Pd., M.Pd. dan Siti Chotimah, S.Pd., M.Pd. yang selama ini telah memberikan arahan dan bimbingannya.

\section{DAFTAR PUSTAKA}

Chotimah, S., Bernard, M., \& Wulandari, S. M. (2018). Contextual approach using VBA learning media to improve students' mathematical displacement and disposition ability. Journal of Physics: Conference Series, 948.

Fristadi, R., \& Bharata, H. (2015). Meningkatkan Kemampuan Berpikir Kritis Siswa Dengan Problem Based Learning. Prosiding Seminar Nasional Matematika Dan Pendidikan Matematika UNY, 597-602. 
Hidayat, W. (2011). Meningkatkan Kemampuan Berpikir Kritis dan Kreatif Matematik Siswa Melalui Pembelajaran Kooperatif Think-Talk-Write (TTW) (Doctoral dissertation, Universitas Pendidikan Indonesia).

Hidayat, W. (2012). Meningkatkan Kemampuan Berpikir Kritis dan Kreatif Matematik Siswa SMA Melalui Pembelajaran Kooperatif Think-Talk-Write (TTW). In Seminar Nasional Penelitian, Pendidikan dan Penerapan MIPA.

Karim, \& Normaya. (2015). Kemampuan Berpikir Kritis Siswa Dalam Pembelajaran Matematika Dengan Menggunakan Model Jucama Di Sekolah Menengah Pertama. EDU-MAT Jurnal Pendidikan Matematika, 3(1), 92-104.

Rosyana, T., \& Sari, I. P. (2015). Penerapan Aktivitas Quick on the Draw melalui Pendekatan Thinking Aloud Pair Problem Solving untuk Meningkatkan Kemampuan Komunikasi dan Penalaran Matematis Siswa MA. Jurnal Ilmiah UPT P2M STKIP Siliwangi, 2(2), 192-202.

Sari, M., Susiswo, \& Nusantara, T. (2016). Analisis Kemampuan Berpikir Kritis Siswa Kelas Viii-D SMP Negeri 1 Gambut. Prosiding Seminar Nasional Pendidikan Sains (SNPS), (November), 232-236.

Sumarmo, U., Hidayat, W., Zukarnaen, R., Hamidah, M., \& Sariningsih, R. (2012). Kemampuan dan Disposisi Berpikir Logis, Kritis, dan Kreatif Matematik (Eksperimen terhadap Siswa SMA Menggunakan Pembelajaran Berbasis Masalah dan Strategi Think-Talk-Write). Jurnal Pengajaran MIPA, 17(1), 17-33.

Tresnawati, T., Hidayat, W., \& Rohaeti, E. E. (2017). Kemampuan Berpikir Kritis Matematis dan Kepercayaan Diri Siswa SMA. Symmetry: Pasundan Journal of Research in Mathematics Learning and Education, 2(2), 39-45.

Widiantari, N., Suarjana, I., \& Kusmariyatni, N. (2016). Analisis Kemampuan Berpikir Kritis Siswa Kelas Iv Dalam Pembelajaran Matematika. Journal PGSD Pendidikan Ganesha, $4(1), 1-3$. 
568 Andriawan, Setiawati, Sari, Chotimah,. Analisis Kemampuan Berpikir Kritis Matematis... 